\title{
A COMPARISON OF PITUITRIN WITH THE ANTIDIURETIC SUBSTANCE FOUND IN HUMAN URINE AND PLACENTA
}

\author{
By GEORGE C. HAM 1 AND EUGENE M. LANDIS \\ (From the Department of Internal Medicine, Hospital of the University of Virginia, \\ Charlottesville)
}

(Received for publication February 16, 1942)

An antidiuretic substance was found by Gilman and Goodman (1) in the urine of normal rats during dehydration, whereas hypophysectomized rats failed to excrete this substance even during dehydration of lethal grade. Their hypothesis that the antidiuretic substance has its origin in the pituitary gland has been both confirmed $(2,3)$ and questioned $(4,5)$. Arnold (4) and Walker (5) found that hypophysectomy failed to reduce uniformly the antidiuretic activity of the urine of dehydrated animals. From this and other evidence it has been suggested that the antidiuretic substance of urine has certain properties differing from those of pituitrin and does not originate in the pituitary gland.

The urine of patients with toxemia of pregnancy contains an antidiuretic substance according to Teel and Reid (6) and Krieger and Kilvington (7). In edema of various types Robinson and Farr (8) found that the antidiuretic activity of the urine was high while fluid was being retained, and low after diuresis had occurred. While Anselmino, Hoffman and Kennedy (9) were able to isolate an antidiuretic and pressor pituitrin-like substance from the blood of patients with toxemia of pregnancy, others have consistently been unable to do so (10 to 16$)$.

The antidiuretic substance found in urine deserves further study, not only because its origin appears to be uncertain, but also because of the important role it might conceivably play in those forms of water retention and edema which so far have not been adequately explained by the purely physical forces included in the Starling hypothesis. The studies reported in this paper (a) confirm the presence of an antidiuretic substance in the urine of patients with toxemia of pregnancy, $(b)$ describe differences between this substance and pituitrin with respect to dialysis, ultracentrifugation, and effect on chloride excretion, and $(c)$ demon-

\footnotetext{
${ }^{1}$ Commonwealth Fund Fellow, 1940-41.
}

strate that placentas from patients with toxemia of pregnancy contain an antidiuretic substance which resembles in certain respects that found in their urine.

\section{METHODS AND MATERIAL}

The antidiuretic substance studied in these experiments was, with the few exceptions noted below, obtained from the urine of patients admitted to the Obstetrical Service ${ }^{2}$ of the Hospital of the University of Virginia, because of hyperemesis gravidarum, hydatid mole, preeclampsia and eclampsia. Urine was collected over accurately timed periods averaging 12 hours. Before and during the collection of urine, patients received adequate amounts of fluid; therapeutic dehydration was delayed until the collection was complete.

Contamination of the urine with feces was avoided, by catheterization if necessary. Immediately after micturition the individual samples were placed in clean glass bottles in a refrigerator, no acid being added. At the end of the 12-hour collection period, the individual samples were pooled. Specific gravity, reaction to litmus, and a rough quantitative estimation of protein were recorded. In some cases the urinary protein was removed by adjusting to $\mathrm{pH} 4.0$ with glacial acetic acid and heating to $80^{\circ}$ C. for 20 minutes, followed by centrifugation and decantation of the supernatant urine. Whether protein was removed or not, the entire specimen was dialyzed against running tap water in an oscillating apparatus containing long cellophane tubes $24 / 32$ inch in diameter and 0.00072 inch thick. Three hours of this dialysis reduced the chloride concentration to undetectable amounts. The dialyzed urine was then concentrated to a volume such that $1 \mathrm{cc}$. represented the urine excreted in 15 to 25 minutes, by boiling the entire specimen in vacuo at $50^{\circ} \mathrm{C}$. To reduce the volume of the specimen to the desired amount required about 3 hours. The concentration of chloride at this point ranged between 1 and $25 \mathrm{~m}$.eq. per liter. The urine concentrate was then stored at $5^{\circ} \mathrm{C}$. for assay on the following day.

The urine of one normal dehydrated subject was treated similarly after collection during the last 12 hours of a 48-hour period with an intake of 800 cc. per 24 hours. Urine from hydrated and dehydrated rats was collected

2 We wish to express our gratitude to Doctor Tiffany Williams for permitting us to study patients on his service and to Doctor W. N. Thornton for his assistance. 
by the method described by Gilman and Goodman (1). The greater volume of urine excreted by the hydrated group was concentrated to the volume excreted over the same period by the dehydrated group, so that the final samples when assayed represented per cc. the same number of minutes of excretion.

For assay of antidiuretic activity, the rat method of Burn (17) was used in modified form. A stock of male albino rats of a Wistar strain were kept in wire-mesh cages, in groups of 3 , in a room maintained at an even temperature. They were fed measured amounts of dog chow checkers at the same time each day. Fresh water was available constantly in a standard drinking cup. This regular feeding and standard drinking equipment were found essential for consistent results. Various described modifications of Burn's rat method and various methods of reading the curves ( 1 to 3,6 to 8,18$)$ were compared, and the results (19) caused the adoption of the following technique, because of its greater dependability and accuracy under the conditions imposed.

Prior to each assay 18 rats were fasted for 12 hours but were allowed to have water ad lib. The next morning they were placed, by groups of 3, in a bank of 6 metabolism cages. The cages were set over 9-inch chemically clean glass funnels which drained into $50 \mathrm{cc}$. graduates. Small conical screens in the apices of the funnels prevented feces from falling into the graduates. The rats were weighed and then distributed so that the total weight of the 3 rats in each group did not differ by more than 10 per cent if possible. Two of the 6 groups were used as controls, leaving 4 groups for duplicate assays of 2 unknown solutions.

To begin the assay procedure, each rat was given by gavage a "priming dose" of 0.2 per cent $\mathrm{NaCl}$ equivalent to 2.5 per cent of body weight. This 0.2 per cent $\mathrm{NaCl}$ solution yielded more consistent results than did gavage with tap water, particularly with respect to excretion of chloride in the urine $(19,21)$. Gavage could be accomplished by one operator easily in the following manner. The rat's tail was clamped to a block on the table with rubber straps and the body was held perpendicularly by placing tension on the neck with the left hand. A number 18 lumbar puncture needle, from which the point had been ground and to which a drop of solder in the form of a small bougie had been added, could then be passed easily with the right hand along the roof of the mouth and the esophagus. The needle was connected to a 100 cc. burette, containing 0.2 per cent $\mathrm{NaCl}$ solution, maintained under pressure of $10 \mathrm{~mm}$. $\mathrm{Hg}$ by compressed air. The desired amount of solution could be run in slowly from the burette without injury, providing the rat was firmly held to prevent flexion of the body. Two hours after this "priming dose" was given, all the urine excreted up to that time was discarded. The volume of urine excreted in this preliminary period varied considerably from group to group and seemed to have no significance except to indicate inequality in voluntary water intake.

Each rat was then given a "hydrating" dose of 0.2 per cent $\mathrm{NaCl}$ solution, equivalent to 5 per cent of the orig- inal weight. Simultaneously, the solution to be assayed was injected intraperitoneally in a volume totaling $1 \mathrm{cc}$. per 100 grams of rat. The control groups were given similar gavage and received intraperitoneally either 0.9 per cent $\mathrm{NaCl}$ solution or distilled water, to match the composition of the solutions being tested.

Starting then at zero time for each cage, the cumulative volume of urine excreted by each group of 3 rats was recorded at 15-minute intervals for 3 hours. The recorded volumes were computed in terms of the amount excreted per 100 grams of rat and plotted against time for each cage, as shown in Figure 1. To express the results by a single number, the areas of these curves were measured in square inches, using a planimeter on the original chart in which one inch represented 30 minutes and $1.0 \mathrm{cc}$. urine. For example, in Figure 1, the control curve enclosed an area (ABCA) of 11.2 sq. in. The curve corresponding to a dose of 1 milliunit of pituitrin per 100 grams of rat had an area (DECD) of 8.7 sq. in.; the difference between the latter and the control was minus $2.5 \mathrm{sq}$. in., indicating slight antidiuretic activity. Pituitrin in a dose of 5 milliunits reduced the area (FGCF) to $2.4 \mathrm{sq}$. in.; the difference from the control area was correspondingly greater, minus 8.8 sq. in., and represented moderate antidiuretic activity.

By this method of expressing results, samples having no effect on water excretion would be represented by curves having areas approximately the same as the controls, and their activity would therefore be designated by a small negative or positive number. Samples having antidiuretic activity would be represented by curves having a smaller area than the controls; the nature and degree of their activity would be designated by a negative number. Conversely, samples having diuretic activity would be represented by curves having a larger area than the controls and their diuretic action would therefore be designated by a positive number.

In 130 experiments, the variation between 2 control cages, observed on the same day, averaged $1.56 \mathrm{sq}$. in. with a maximal variation of $5 \mathrm{sq}$. in., the latter occurring in only 2 experiments. In this paper, urine concentrates producing numerical values between zero and minus $2 \mathrm{sq}$. in. are termed "inactive"; between minus 2 and minus 4 sq. in., "slightly antidiuretic"; between minus 4 and minus 9 sq. in., "moderately antidiuretic"; and minus 9 or more sq. in., "markedly antidiuretic."

The urine excreted by each group, during the 3-hour collection period, was analyzed for chloride by the open Carius method of the Volhard titration as described by Van Slyke and Sendroy (20). Chloride excretion was recorded in terms of total microequivalents ${ }^{3}$ per 100 grams of rat during the entire 3-hour period.

\section{OBSERVATIONS}

\section{Dependability and limitations of the method}

In preliminary observations, using known amounts of pituitrin, it was found that the method

\footnotetext{
${ }^{3}$ Microequivalents $=$ equivalents $\times 10^{-6}$.
} 


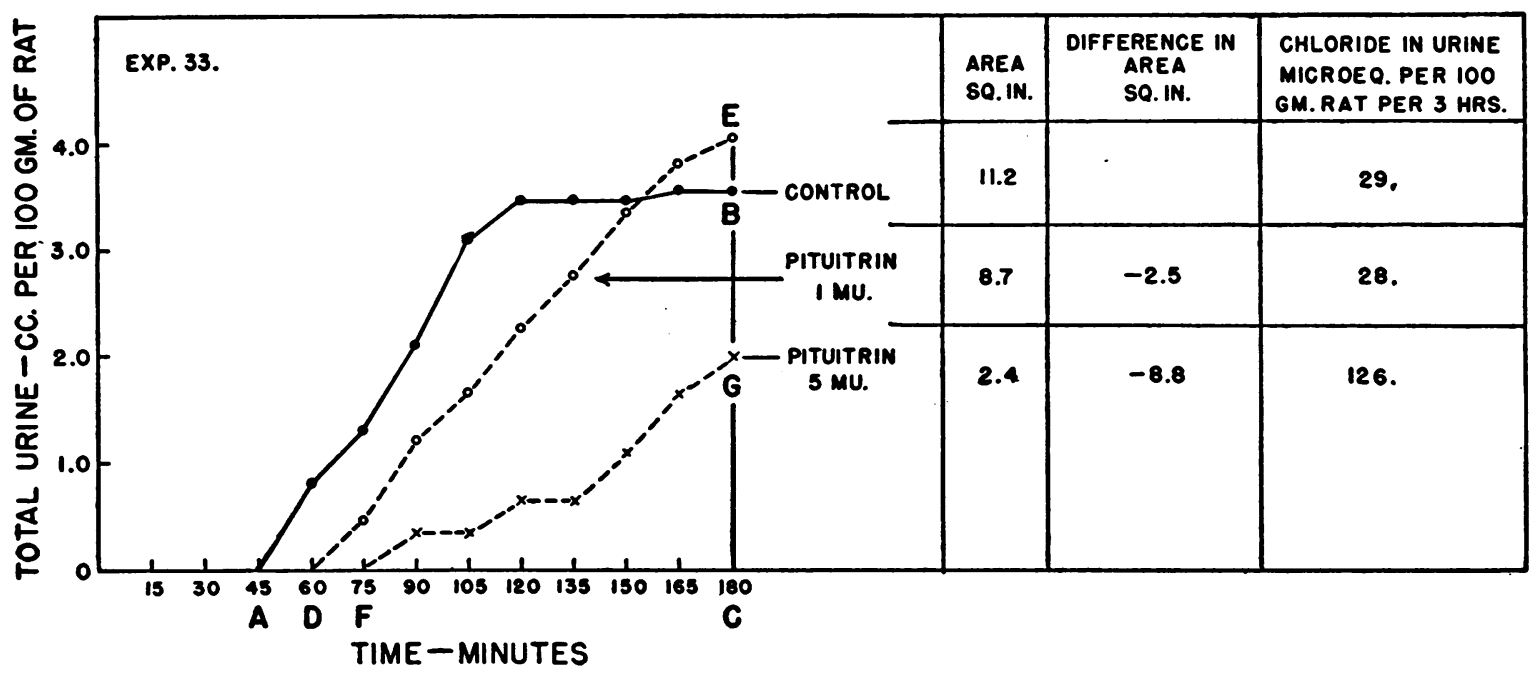

Fig. 1. Showing Typical Diuresis Curves of Groups of Rats Receiving a Control Injection (B), and 1 (E), or 5 (G) milliunits of Pituitrin per 100 Grams (For full description see text)

described was quite accurate with doses of 0.5 to 10 milliunits of pituitrin per 100 grams of rat. Doses larger than this produced curves with areas slightly greater than those for 10 milliunits and hence paradoxically smaller numerical values for antidiuresis. Examination of these curves revealed that doses exceeding 10 milliunits per 100 grams of rat produced a brief diuresis and then, secondarily, a profound antidiuresis, whereas the smaller doses produced antidiuresis only. This effect has been described before with larger doses and may be related to the temporary rise in blood pressure produced by pituitrin. Since the expression of results in terms of area includes the total effect, it is essential, with pituitrin at least, to dilute the sample of unknown potency to the proper range to obtain accurate quantitative results.

Although the larger doses of pituitrin had a paradoxically smaller total antidiuretic activity over the 3-hour period chosen, their effect on excretion of $\mathrm{Cl}$ in the urine, or their "chloruretic" 4 activity, increased steadily as the dose of pituitrin increased over a range of 0.1 to 100 milliunits per 100 grams of rat. In fact, comparison showed, in agreement with the prediction made by Silvette (21), that pituitrin solutions may be assayed more accurately by measuring their effect on $\mathrm{Cl}$ excretion, than by measuring their antidiuretic activity

4 Chloruretic: G. chlōros, yellowish green; plus G. ourēsis, urination; urination of chlorides. alone. These findings apply only indirectly to the problem being reported here and will be described more fully in another paper (19).

Because repeated injections of the colloidal constituents of urine into the same rats at intervals of days or weeks might produce artefacts due to anaphylaxis, it was at first thought necessary to use fresh rats for each assay. However, when the same urine concentrates, with and without protein, were injected into the same rats after various intervals ranging from 7 to 27 days, no difference in the curves of water excretion could be detected, nor was there any gross evidence of anaphylaxis. As a further test $1 \mathrm{cc}$. of human blood serum was injected into each of 6 rats and repeated 20 days later. The curves of water excretion were the same. Therefore as long as the rats ate well, maintained their weight, and were not obviously abnormal, they were used for not more than 3 assays at intervals of 10 days or more.

\section{The antidiuretic activity of human and rat urine under various conditions}

The results reported for rats by Gilman and Goodman (1), and for human beings by Teel and Reid (6) and Krieger and Kilvington (7), were confirmed in part (Figure 2 and Table I). No attempt was made to study a large series of cases, these results being listed merely to amplify the reports already published and to describe the source of the material studied. 


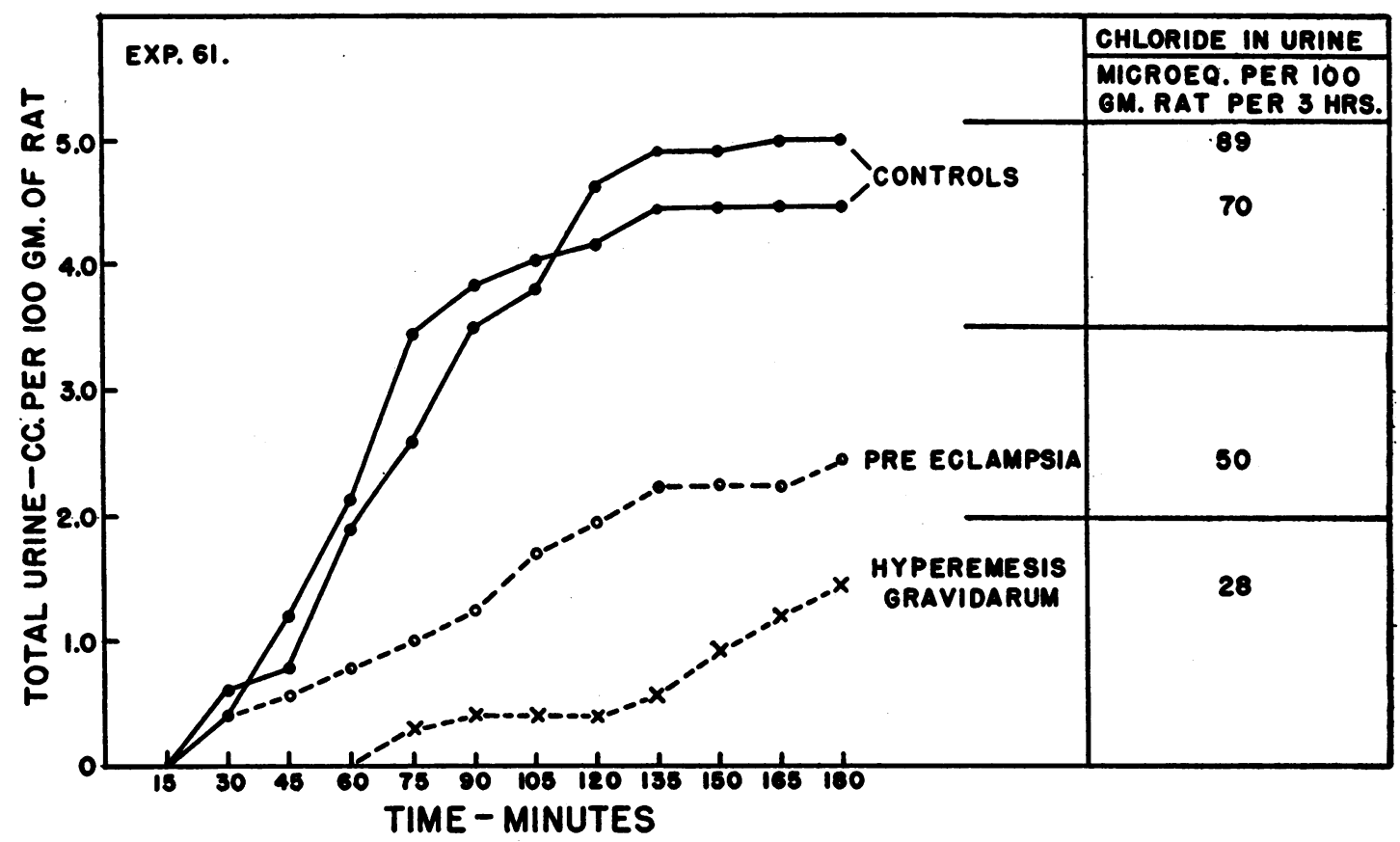

Fig. 2. Showing the Antidiuretic Activity of Urine from a Patient with Preeclampsia and from a Patient with Hyperemesis Gravidarum

TABLE I

Showing sources of urine studied, number of cases, and antidiuretic activity of each specimen

\begin{tabular}{|c|c|c|c|c|c|c|}
\hline & \multirow{2}{*}{ Source of urine } & \multirow{2}{*}{$\begin{array}{c}\text { Number } \\
\text { of } \\
\text { cases }\end{array}$} & \multicolumn{4}{|c|}{$\begin{array}{l}\text { Antidiuretic activity, } \\
\text { each specimen }\end{array}$} \\
\hline & & & None & Slight & $\begin{array}{l}\text { Mod- } \\
\text { erate }\end{array}$ & Marked \\
\hline \multirow{2}{*}{ Rats } & Water ad lib. & $\begin{array}{l}2 \text { groups } \\
12 \text { each }\end{array}$ & 2 & & & \\
\hline & Dehydrated 48 hours & $\begin{array}{l}2 \text { groups } \\
12 \text { each }\end{array}$ & & & 1 & 1 \\
\hline \multicolumn{2}{|c|}{$\begin{array}{l}\text { Normal subjects } \\
\text { Male 1, Female } 2 \\
\end{array}$} & 3 & 3 & & & \\
\hline \multicolumn{2}{|c|}{$\begin{array}{l}\text { Normal subject, dehydrated } \\
\text { Female } 1\end{array}$} & 1 & & & 1 & \\
\hline \multicolumn{2}{|c|}{$\begin{array}{l}\text { Chronic glomerulonephritis } \\
\text { with edema }\end{array}$} & 2 & 2 & & & \\
\hline \multicolumn{2}{|c|}{ Preeclampsia } & 6 & 1 & & 3 & 3 \\
\hline \multicolumn{2}{|c|}{ Eclampsia } & 2 & & & 1 & 1 \\
\hline \multicolumn{2}{|c|}{ Hyperemesis gravidarum } & 3 & & & 4 & 2 \\
\hline \multicolumn{2}{|c|}{ Hydatid mole } & 1 & & & 1 & 1 \\
\hline
\end{tabular}

The urine from dehydrated rats was moderately or markedly antidiuretic (Table I), while the urine of rats taking water ad lib. was inactive, even though the assay animals received quantities of dialyzed urine equivalent to the same number of minutes of urinary excretion by the dehydrated rats. The antidiuretic substance in these specimens of rat urine was found to have the same properties as the antidiuretic factor in human urine and will therefore not be discussed separately from this point on.

. Three normal human beings, taking water ad lib., did not excrete detectable amounts of antidiuretic substance (Table I), whereas 1 female subject, dehydrated to a moderate degree, excreted a moderate amount of antidiuretic substance. Two patients with chronic glomerulonephritis and edema excreted urine without antidiuretic activity; the edema was explained adequately in these patients by advanced hypoproteinemia. In the remaining 12 cases, all suffering from complications of pregnancy, moderate or marked antidiuretic activity was observed in 16 urine specimens, and no activity in 1 specimen. The cases diagnosed "preeclampsia" presented clinical edema, albuminuria, and some degree of hypertension, while those diagnosed "eclampsia" had, in addition to these abnormalities, at least one generalized convulsion. Figure 2 illustrates the typical results of an assay 
of urine from a patient with preeclampsia, and shows a curve indicating moderate antidiuretic activity.

In Figure 2 is included also the result of an assay on the urine of a patient with hyperemesis gravidarum. The presence of antidiuretic substance in the urine of patients with hyperemesis gravidarum and hydatid mole has not been previously reported. The results in Table I indicate that antidiuretic substance appears in the urine of these patients quite uniformly in amounts as great as those found in preeclampsia and eclampsia. In cases of hyperemesis gravidarum, the specimens of urine were obtained during the first 12 hours in the hospital, while fluids were being administered. One patient in this group received, during 72 hours, $6000 \mathrm{cc}$. of 5 per cent glucose in 0.9 per cent $\mathrm{NaCl}$ intravenously. While the urine collected on the first day was markedly antidiuretic, that collected on the third day was only moderately antidiuretic. The presence of antidiuretic substance in the urine of these patients may be merely the result of the dehydration accompanying the condition. The patient with hydatid mole had all the symptoms and signs of severe preeclampsia and the correct diagnosis was made only after the mole was delivered.

\section{The effect of dialysis on the antidiuretic activity of pituitrin solutions and of human urine}

Gilman and Goodman (1) found that the antidiuretic fraction of pituitrin solution was retained by the dialyzing sacs they used, whereas Walker (5) reported at least a 50 per cent loss of antidiuretic activity when pituitrin, either in saline or in rat urine, was dialyzed. Our findings agree with those of Walker, in that pituitrin added to human or rat urine dialyzed as rapidly as when added to distilled water. There was no evidence that contact with human urine diminished the dialyzability of pituitrin or of its antidiuretic and chloruretic fractions.

Table II illustrates a typical experiment. A pituitrin $^{5}$ solution containing 10 milliunits per cc. in distilled water was injected in the usual dose of $1.0 \mathrm{cc}$. per 100 grams of rat. This originally produced antidiuresis amounting to minus 7.0 sq. in.

5 Obstetrical pituitrin, Parke Davis, lot No. 3260690, 1 cc. containing 10 international units. but after dialysis for 3 hours, lost its antidiuretic activity completely, producing a curve with an area of plus $2.1 \mathrm{sq}$. in. In contrast, the antidiuretic substance of urine did not dialyze. To make conditions as similar as possible, 2 aliquots of 1 urine sample were dialyzed, 1 for 3 hours and 1 for 6 hours, then concentrated so that $1 \mathrm{cc}$. of each specimen corresponded to 24 minutes of urine secretion. They were assayed on the same day for comparison with each other and the same controls. As shown in Table II, after the routine 3-hour dialysis required to free the urine of salts, the first sample produced antidiuresis amounting to minus 5.5 sq. in. Further dialysis of this urine for an additional 3 hours did not change its antidiuretic activity significantly, the figure at 6 hours being minus 6.2 sq. in.

The effect of pituitrin on chloride excretion was also decreased by dialysis from 239 microequivalents per 100 grams of rat to 71 microequivalents per 100 grams, the latter being within the normal range of the controls. As usual (compare Figures 1 and 2) dialyzed urine, even when conspicuously antidiuretic, had no effect on chloride excretion at any time.

Similar results were obtained in 6 such comparisons. The retention by cellophane of the antidiuretic substance in urine persisted whether or not the urine was first freed of protein by acid and heat. Walker (5) has called attention to differences in the permeability of various samples

TABLE. II

The effect of dialysis on the antidiuretic activity of pituitrin and of human urine

\begin{tabular}{|c|c|c|c|c|}
\hline $\begin{array}{c}\text { Experi- } \\
\text { ment } \\
\text { num- } \\
\text { ber }\end{array}$ & Substance and dose & Treatment & $\begin{array}{l}\text { Anti- } \\
\text { diuretic } \\
\text { activity }\end{array}$ & $\begin{array}{l}\text { Total } \\
\text { 3-hour } \\
\text { chloride } \\
\text { excretion } \\
\text { in the } \\
\text { urine }\end{array}$ \\
\hline \multirow{3}{*}{84} & $\begin{array}{l}\text { Distilled water, } 1.0 \mathrm{cc} \text {. } \\
\text { per } 100 \text { grams of rat }\end{array}$ & Control & $\begin{array}{c}\text { sq. in. } \\
0\end{array}$ & $\begin{array}{l}\text { Micro- } \\
\text { equivalents } \\
\text { per } 100 \\
\text { grams } \\
34\end{array}$ \\
\hline & \multirow{2}{*}{$\begin{array}{l}\text { Pituitrin, } 10 \text { milliunits in } \\
1.0 \mathrm{cc} \text {. distilled water } \\
\text { per } 100 \text { grams of rat }\end{array}$} & Undialyzed & -7.0 & 239 \\
\hline & & $\begin{array}{r}\text { Dialyzed } \\
3 \text { hours }\end{array}$ & +2.1 & 71 \\
\hline \multirow{3}{*}{18} & $\begin{array}{l}\text { Distilled water, } 1.0 \mathrm{cc} \text {. } \\
\text { per } 100 \text { grams of rat }\end{array}$ & Control & $\mathbf{0}$ & 7 \\
\hline & \multirow{2}{*}{$\begin{array}{l}\text { Urine, hyperemesis } \\
\text { gravidarum, } 24 \text { minutes' } \\
\text { excretion in } 1 \text { cc. } \\
\text { distilled water per } \\
100 \text { grams of rat }\end{array}$} & $\begin{array}{r}\text { Dialyzed } \\
3 \text { hours } \\
\end{array}$ & -5.5 & 6 \\
\hline & & $\begin{array}{r}\text { Dialyzed } \\
6 \text { hours }\end{array}$ & -6.2 & 14 \\
\hline
\end{tabular}


of cellophane of the same thickness. It seems safe to conclude, however, that the antidiuretic substance of pituitrin passes through a cellophane membrane of suitable thickness far more easily than the antidiuretic substance found in human or rat urine.

\section{The effect of ultracentrifugation on the anti- diuretic factor in pituitrin and in human urine}

An ultracentrifuge (23) with a $10^{\circ}$ angle rotor (24) was used to compare the rate of sedimentation of these 2 antidiuretic substances. Seven samples of pituitrin in distilled water, in concentrations ranging from 2.75 to 27.5 milliunits per cc., were ultracentrifuged at 60,000 r.p.m. for periods of 4 to 6 hours. Eight samples of urine known to contain antidiuretic substance were treated in the same manner. At the end of the period of ultracentrifugation, the solutions were divided into 4 equal fractions numbering the uppermost, 1 and the lowermost, 4. Each fraction was assayed in the usual manner for its antidiuretic activity.

Figure 3 shows the results of a typical experiment. The antidiuretic activity of all 4 fractions of the pituitrin solution remained the same (Figure 3, upper) indicating that the antidiuretic substance of pituitrin had not been measurably concentrated by the ultracentrifuge. On the contrary, the upper 3 fractions of human urine became essentially inactive after ultracentrifugation while the fourth or lowermost fraction exerted an antidiuretic effect which was significantly greater than that of the original urine and far greater than that of the other 3 fractions of the same sample (Figure 3, lower).

Chloride excretion was high for all 4 fractions of the pituitrin solutions, corresponding in general magnitude to antidiuretic activity. Very slight concentration of pituitrin may have occurred in that the chloride concentration of the urine from the assay animals was 238 microequivalents per 100 grams for fraction 1 and 358 microequivalents per 100 grams for fraction 4 . The antidiuretic substance of urine, however, had no effect on chloride excretion, even in fraction 4 which produced more antidiuresis than any of the fractions containing pituitrin in this comparison. Chloride excretion was in the normal range and less than one-twentieth of that produced by pituitrin.

Figure 4 summarizes all of the results obtained. The grade of antidiuresis, expressed in sq. in. is indicated by the ordinate in the center of the chart. The activity of the top (1), middle (2 and 3) and bottom (4) fractions are indicated from left to right. Points referring to individual samples are connected by light lines while the heavy lines represent averages. The concentrations of the pituitrin solutions were varied to match the different intensities of antidiuretic activity exhibited by the samples of urine before ultracentrifugation.

With ultracentrifuged pituitrin, the variations in the 4 fractions of any 1 sample were within the admittedly large limits of experimental error in the assay method. No consistent difference existed, however, in the activity of the first and fourth fractions, as shown by the individual experiments and by the mean of 7 experiments. With ultracentrifuged urine, on the contrary (Figure 4 , left), the fourth, or bottom, fraction in 8 individual experiments always had greater antidiuretic activity than the first, or top, fraction and the mean of these experiments slopes upward significantly for fraction 4. Moreover, in each experiment the antidiuretic activity of the fourth fraction was greater than that of the same urine before centrifugation. Prior removal of protein from urines containing small or large amounts did not alter the results.

In summary, the antidiuretic principle of commercial pituitrin cannot be concentrated by the ultracentrifuge, while the antidiuretic factor in urine can be concentrated readily by this method. The results agree with those to be expected from differences in dialyzability and suggest that the antidiuretic substance of urine either is, or is attached to, a larger molecule than the antidiuretic substance of commercial pituitrin.

\section{Properties of fresh extract and press juice of the posterior lobe of the pituitary gland with respect to dialysis and ultracentrifugation}

Rosenfeld (25) has called attention to certain differences between the physical properties of the "native" hormone of the pituitary gland and those of commercially purified pituitrin but he studied only the pressor and oxytocic fractions. It seemed 


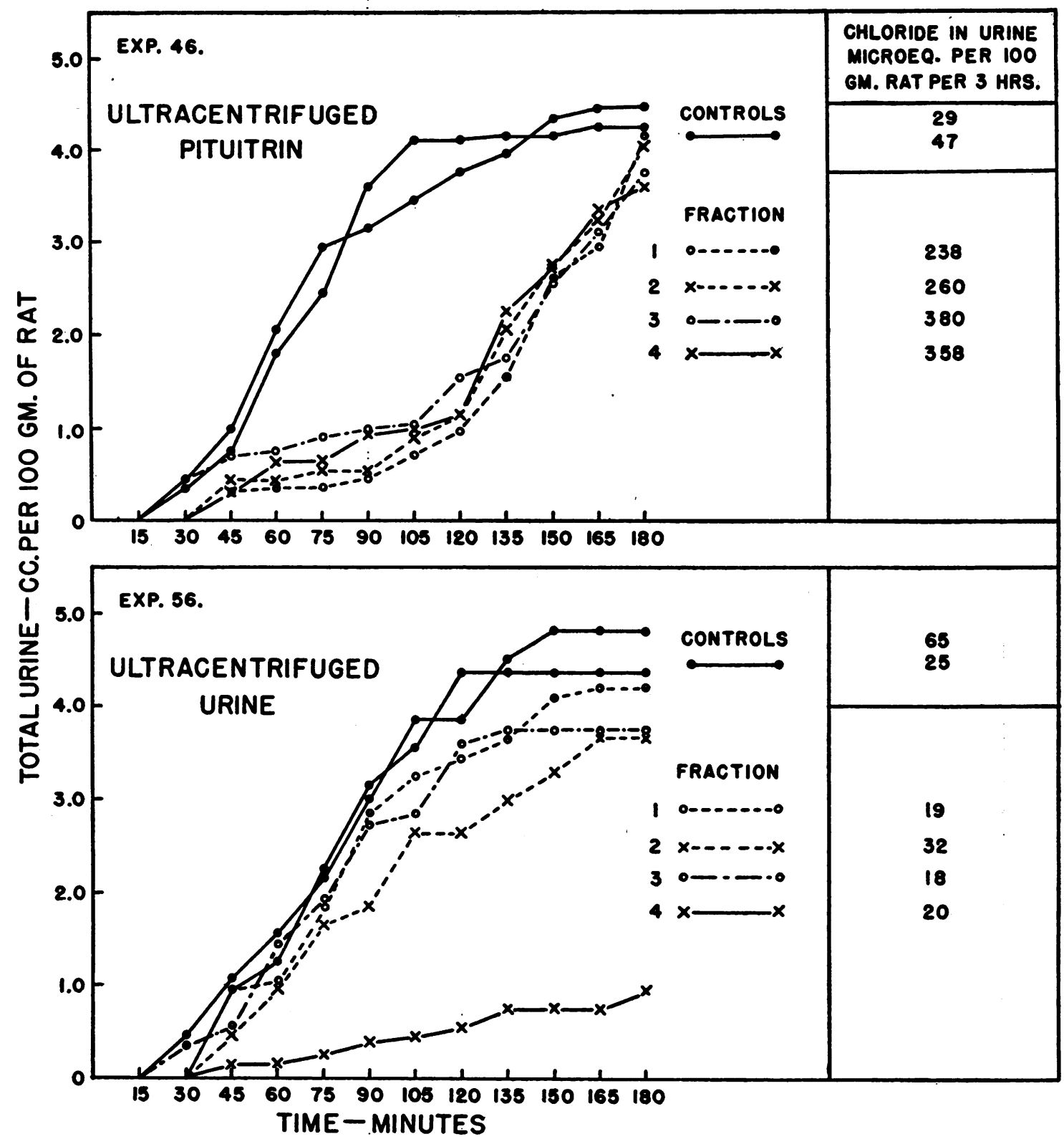

Fig. 3. Upper: Showing the Antidiuretic Activity of Ultracentrifuged Pituitrin in 4 Fractions, Numbered 1 to 4 from Above Downward. Lower: Showing the Antidiuretic Activity of Ultracentrifuged Potent Urine in 4 Fractions, Similarly Numbered

desirable to extend these observations to antidiuretic and chloruretic activity of the "native" hormone, because pituitrin might not be wholly representative of the hormone as it exists in the body.

Saline extracts were prepared from the posterior lobes of beef pituitary glands, which had been kept solidly frozen since their removal from the animals shortly after death. Five to 10 grams, wet weight, of material were alternately thawed at room temperature and frozen by dry ice 5 times. Sufficient 0.9 per cent $\mathrm{NaCl}$ solution at $5^{\circ} \mathrm{C}$. was added to make a 10 per cent extract and the entire mixture was triturated in a porcelain mortar with finely ground glass until homogeneous. This reddish-brown solution was then filtered through 


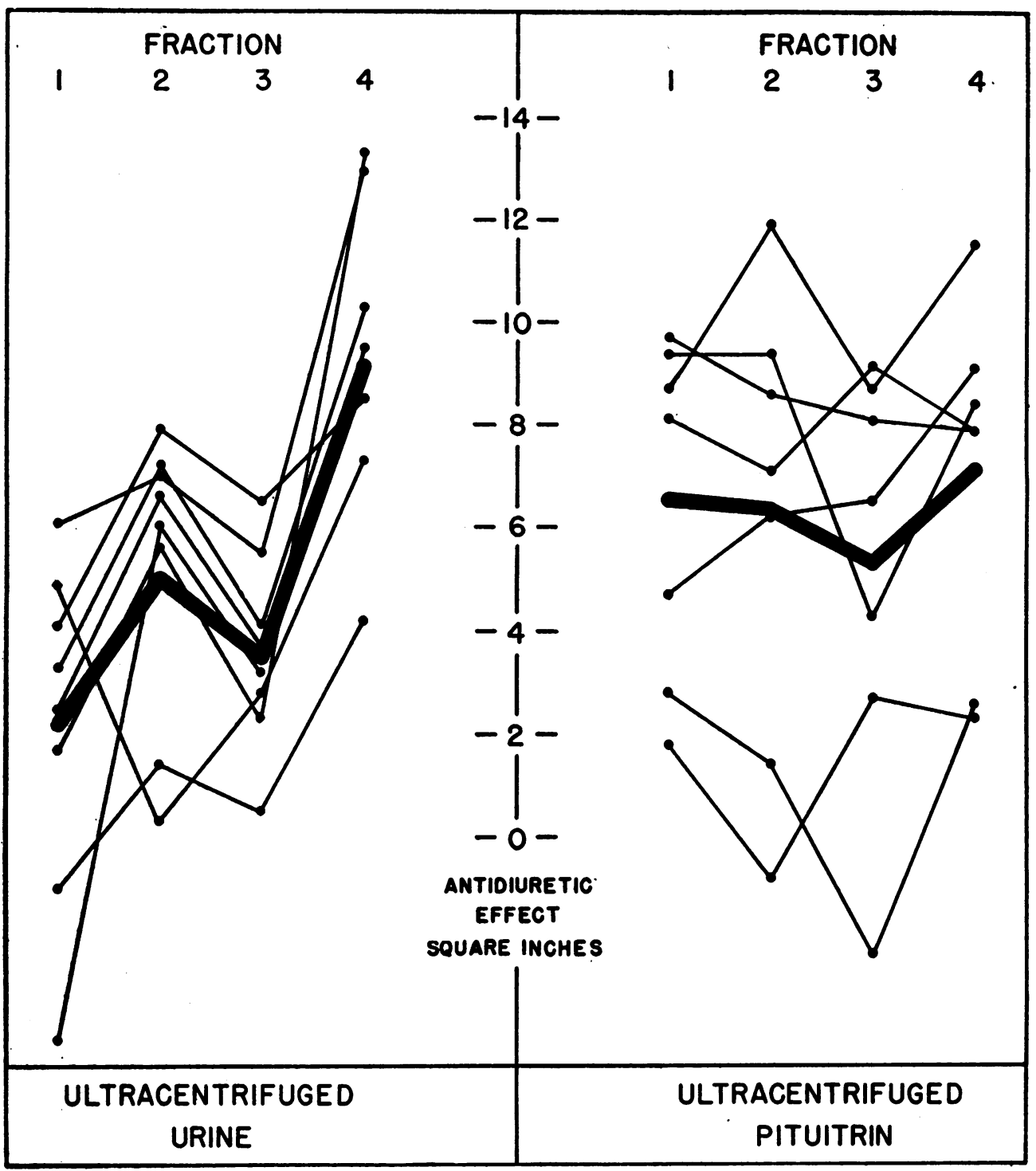

Fig. 4. Showing the Effects of Ultracentrifuged Pituitrin Solutions and Potent Urines (Fractions are numbered as in Figure 3)

Whatman No. 1 filter paper and stored at $5^{\circ} \mathrm{C}$. The cloudy, opalescent filtrate was found to have marked antidiuretic and chloruretic activity. Several preliminary experiments indicated that the appropriate concentration for the rat assay method lay between 0.005 per cent and 0.05 per cent.

As shown in Table III, dialysis of these solutions in cellophane sacs for 3 hours reduced but did not abolish the antidiuretic and chloruretic activity of the original extract. Though the antidiuretic and chloruretic fractions in fresh extract are apparently dialyzable, it appears that for a given membrane and a given period of oscillating dialysis, the antidiuretic fraction of commercial pituitrin passes through the membrane more rapidly than does the antidiuretic fraction from freshly extracted glands. Ultracentrifugation in 12 experiments on 4 different saline extracts showed that the antidiuretic and chloruretic activity of the bottom fraction was distinctly greater than that of the top fraction, as shown in Table III. It seems, therefore, that the antidiuretic and chloruretic fractions in fresh saline extract are attached to larger molecules, than is the case in 
TABLE III

The effect of dialysis and ultracentrifugation on the antidiuretic and chloruretic activity of saline extracts of the posterior lobe of the pituitary gland

\begin{tabular}{|c|c|c|c|c|}
\hline $\begin{array}{c}\text { Ex- } \\
\text { peri- } \\
\text { ment } \\
\text { num- } \\
\text { ber }\end{array}$ & $\begin{array}{c}\text { Substance and } \\
\text { dose }\end{array}$ & Treatment & $\begin{array}{c}\text { Antidiuretic } \\
\text { activity }\end{array}$ & $\begin{array}{l}\text { Total } \\
\text { 3-hour } \\
\text { chloride } \\
\text { excretion } \\
\text { in the } \\
\text { urine }\end{array}$ \\
\hline 86 & $\begin{array}{l}0.005 \text { per cent } \\
\text { Post. Pit. } \\
\text { Extract No. } 2\end{array}$ & $\begin{array}{l}\text { Undialyzed } \\
\text { Dialyzed } \\
3 \text { hours }\end{array}$ & $\begin{aligned} & \text { sq. in. } \\
&-6.8 \\
&-3.7\end{aligned}$ & $\begin{array}{c}\text { Micro- } \\
\text { equivalents } \\
\text { per 100 } \\
\text { grams } \\
279 \\
172\end{array}$ \\
\hline 123 & $\begin{array}{l}0.005 \text { per cent } \\
\text { Post. Pit. } \\
\text { Extract No. } 4\end{array}$ & $\begin{array}{l}\text { Ultracentrifuged } \\
7 \text { hours at } \\
62,000 \text { r.p.m. }\end{array}$ & $\begin{array}{l}\text {-1.2 Top } \\
-8.2 \text { Bottom }\end{array}$ & $\begin{array}{r}27 \\
191\end{array}$ \\
\hline 124 & $\begin{array}{l}0.025 \text { per cent } \\
\text { Post. Pit. } \\
\text { Extract No. } 4\end{array}$ & $\begin{array}{l}\text { Ultracentrifuged } \\
7 \text { hours at } \\
62,000 \text { r.p.m. }\end{array}$ & $\begin{array}{l}-0.4 \text { Top } \\
-4.6 \text { Bottom }\end{array}$ & $\begin{array}{r}52 \\
260\end{array}$ \\
\hline
\end{tabular}

commercial pituitrin which has been treated by acid. At first sight it might appear impossible that the active substance of saline extract can be dialyzable, at least slowly and partially, and also be concentrated by the ultracentrifuge. Rosenfeld (25) has reported, however, that in untreated press juice of the posterior lobe of the pituitary, the pressor and oxytocic principles exist in the form of a single large molecule or 2 separate large molecules which by ultracentrifugation appear to have similar sedimentation rates. Because of the mild extraction method used, he believes these large molecules to be the "native" hormone. Rosenfeld showed further that pituitrin, pitressin and pitocin contained the active pressor and oxytocic principles in the form of physiologically effective cleavage products which have much smaller molecular weights than the "native" hormone.

This preponderance of "native" hormone of large molecular size in aqueous extract and press juice makes it possible to explain the apparent discrepancy mentioned above. Saline extract may initially contain "native" hormone for the most part with a small amount of the active cleavage product, the latter being dialyzable, the former undialyzable. It would then be expected that dialysis of the split hormone would lead slowly to further cleavage and more dialysis of antidiuretic substance. This process, continued long enough, would reduce the potency of the sample within the dialyzing sac but at a slower rate than would the same dialysis of pure split products such as those found in commercial pituitrin. On the other hand, ultracentrifugation would not disturb the ratio of "native" and split hormone so that the active antidiuretic and chloruretic substance could be concentrated largely in the lowermost fraction.

To test this explanation, press juice was prepared by Dr. Morris Rosenfeld, ultracentrifuged, separated into 2 or 3 fractions, and then shipped to us for assays of antidiuretic and chloruretic activity. The top and bottom fractions of each sample were assayed in 12 experiments, using various concentrations in distilled water or 0.9 $\mathrm{NaCl}$ solution. Representative results are summarized in Table IV. In all experiments the antidiuretic and chloruretic factors were more concentrated in the lower fraction, though significant action was still perceptible in the top fraction in 2 of the experiments shown. In other respects also, as will be reported separately (22), the cleavage of the antidiuretic fraction in saline extracts resembles that of the pressor and oxytocic fractions of press juice.

In summary, the antidiuretic principle of the "native" hormone of the posterior pituitary gland still dialyzes but at a definitely slower rate than does the same principle in commercial pituitrin. Ultracentrifugation concentrates, at least partially, the antidiuretic principle of the "native" hormone, but does not concentrate that of pituitrin.

TABLE IV

The effect of ultracentrifugation on the antidiuretic and chloruretic activity of 4 different preparations of press juice

\begin{tabular}{|c|c|c|c|}
\hline $\begin{array}{c}\text { Exper- } \\
\text { iment } \\
\text { num- } \\
\text { ber }\end{array}$ & Substance and dose & $\begin{array}{l}\text { Antidiuretic } \\
\text { activity }\end{array}$ & $\begin{array}{l}\text { Total 3-hour } \\
\text { chloride ex- } \\
\text { cretion in } \\
\text { the urine }\end{array}$ \\
\hline 95 & $\begin{array}{l}0.1 \mathrm{cc} \text {. press juice No. } 1 \text { diluted } \\
\text { to } 80 \mathrm{cc} \text { with distilled water } \\
1.0 \mathrm{cc} \text {. per } 100 \text { grams of rat }\end{array}$ & $\begin{array}{c}\text { sq. in. } \\
-1.2 \text { Top } \\
-4.8 \text { Bottom }\end{array}$ & $\begin{array}{c}\text { Microequia- } \\
\text { alents per } \\
100 \text { grams } \\
79 \\
230\end{array}$ \\
\hline 108 & $\begin{array}{l}0.1 \text { cc. press juice No. } 2 \text { diluted } \\
\text { to } 80 \text { cc. with } 0.9 \text { per cent } \\
\mathrm{NaCl} \text {. } \\
1.0 \mathrm{cc} \text {. per } 100 \text { grams of rat }\end{array}$ & $\begin{array}{c}-4.9 \text { Top } \\
-10.1 \text { Bottom }\end{array}$ & $\begin{array}{r}68 \\
218\end{array}$ \\
\hline 114 & $\begin{array}{l}0.1 \text { cc. press juice No. } 3 \text { diluted } \\
\text { to } 120 \text { cc. with } 0.9 \text { per cent } \\
\mathrm{NaCl} \text {. } \\
1.0 \mathrm{cc} \text {. per } 100 \text { grams of rat }\end{array}$ & $\begin{array}{c}-2.2 \text { Top } \\
-7.9 \text { Bottom }\end{array}$ & $\begin{array}{l}154 \\
294\end{array}$ \\
\hline 125 & $\begin{array}{l}0.1 \text { cc. press juice No. } 4 \text { diluted } \\
\text { to } 100 \text { cc. with distilled water. } \\
1.0 \text { cc. per } 100 \text { grams of rat }\end{array}$ & $\begin{array}{l}\text { +0.60 Top } \\
-5.5 \text { Bottom }\end{array}$ & $\begin{array}{r}37 \\
161\end{array}$ \\
\hline
\end{tabular}


6. Comparative effect of pituitrin, saline pituitary extract, pituitary press juice, and the antidiuretic substance of urine, on excretion of the chloride in the urine (chloruresis),

It is well known that pituitrin, in addition to its pressor, oxytocic, and antidiuretic effects, also increases the excretion of chloride in the urine. Even during marked antidiuresis the total excretion of chloride over a given time exceeds manyfold the normal total excretion of chloride. The concentration of chloride per unit volume of urine shows, of course, even more striking increase. Because pituitrin, so far as is known at present, is the only substance which produces simultaneous antidiuresis and chloruresis, it seemed desirable to study the action of the antidiuretic substance of urine in this respect.

The total chloride excreted during 3 hours by each group of assay rats, is shown in Figure 5. Total chloride excretion, in terms of microequivalents per 100 grams of rat in 3 hours, is shown on the ordinate and plotted against the antidiuretic activity of the same sample of urine, in sq. in., on the abscissa. The dotted line, just below 90 microequivalents, indicates the maximal chloride excretion observed in animals receiving control injections. For the sake of clearness, individual control values are not shown. Pituitrin (open circles), crude extracts of fresh pituitary glands (crosses), and press juice of fresh pituitary gland

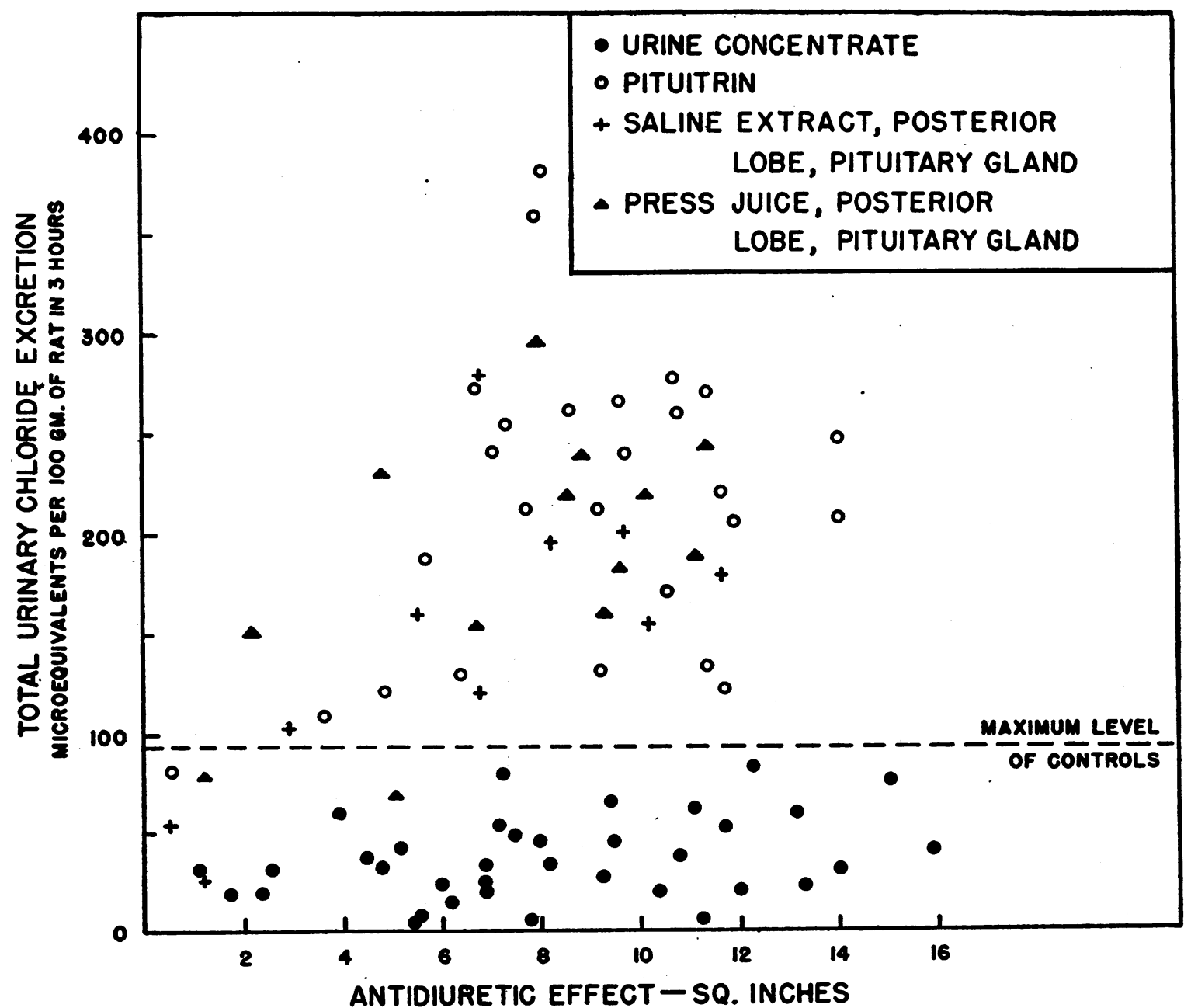

Fig. 5. Showing the Relation Betwern the Antidiuretic and Chloruretic Activity of Urine Concentrates (Dots), Pituitrin (ctrcles), Saline Extract of the Posterior Lobe of the Pituitary Gland (crosses), and Press Juice of the Posterior Lobe of the Pituitary Gland (triangles) 
(solid triangles) increased the excretion of chloride roughly in proportion to the grade of antidiuresis. Total chloride excretion by the assay animals receiving pituitary products was above the maximal level of the control experiments, except for 5 instances in which the dose of pituitary products was so small that the antidiuretic effect was barely detectable. Thus the "native" hormone and its derivative, pituitrin, were chloruretic as well as antidiuretic and this relation held, irrespective of differences in dialyzability or. molecular size. There was no evidence that the antidiuretic and chloruretic effects could be separated.

In striking contrast dialyzed and concentrated urine (solid dots, Figure 4), even when conspicuously antidiuretic, never increased chloride excretion above the level of the controls.

\section{The antidiuretic activity of placental extracts}

The observations so far described suggest that the antidiuretic substance of urine differs in certain important respects from the antidiuretic principle of the pituitary gland and may conceivably arise elsewhere as suggested by Walker (5). If this be true, other sources of antidiuretic material must be considered. Because conspicuous diuresis usually follows parturition in patients with toxemia of pregnancy, it seemed logical to investigate the placenta first. Saline extracts of 11 fresh placentas were studied, 6 from women delivered after normal pregnancy and 5 from women delivered in the course of a toxemia of pregnancy.

The freshly delivered placentas were taken immediately to the laboratory. The cord and membranes were carefully dissected away and the surface of the placenta was gently washed free of blood clots. A careful examination of the surface for fresh or old infarcts was followed by multiple sectioning and observation of the cut surface. The whole placenta was then cut into small pieces with scissors and passed through a coarse meat grinder and weighed. An equal amount of 0.9 $\mathrm{NaCl}$ solution was then added and the entire mixture was ground at a temperature not over $20^{\circ} \mathrm{C}$. in an Eppenbach colloid mill until completely homogeneous. This mixture was filtered through 3 thicknesses of surgical gauze and the filtrate centrifuged. The supernatant fluid was decanted and dialyzed in cellophane tubes against running tap water for 3 hours on an oscillating platform. The dialyzed material was stored at $5^{\circ} \mathrm{C}$. and bio-assay completed the next day.

Figure 6 compares the results observed with an extract of normal placenta (above) and a placenta from a patient with toxemia (below). The 50 per cent extract of normal placenta was inactive; the same was true of a 250 per cent extract concentrated by evaporation from the frozen state and redissolved in one-fifth the original volume of water. In contrast, 50 and 25 per cent extracts of the placenta from a patient with toxemia of pregnancy were markedly and moderately antidiuretic respectively.

The antidiuretic activities of all the extracts studied are summarized in Table V. With 1 notable exception (experiment 69), the extracts of all normal placentas were slightly diuretic, inactive, or slightly antidiuretic. No logical explanation can be offered for the moderate activity observed in experiment 69 . The patient was a 21 -year-old colored primigravida in good health, without edema, albuminuria, or hypertension. She had a normal and uneventful delivery and puerperium. It is conceivable that changes in the placenta had occurred too recently in this case to produce systemic effect.

Extracts of placentas from patients with toxemia of pregnancy were moderately to markedly antidiuretic, again with one notable exception, experiment 112 , in which the extract was only

TABLE V

\begin{tabular}{|c|c|c|c|}
\hline \multicolumn{2}{|c|}{ Normal subjects } & \multicolumn{2}{|c|}{$\begin{array}{l}\text { Patients with toxemia } \\
\text { of pregnancy }\end{array}$} \\
\hline $\begin{array}{l}\text { Experiment } \\
\text { number }\end{array}$ & $\begin{array}{l}\text { Antidiuretic } \\
\text { activity }\end{array}$ & $\begin{array}{l}\text { Experiment } \\
\text { number }\end{array}$ & $\begin{array}{l}\text { Antidiuretic } \\
\text { activity }\end{array}$ \\
\hline $\begin{array}{r}62 \\
71 \\
106 \\
104 \\
107 \\
69\end{array}$ & $\begin{array}{l}\text { sq. in. } \\
-0.7 \\
-4.0 \\
+0.7 \\
+1.7 \\
-2.4 \\
-6.9\end{array}$ & $\begin{array}{r}55 \\
68 \\
75 \\
112 \\
63\end{array}$ & $\begin{array}{c}\text { sq. in. } \\
-7.3 \\
-12.6 \\
-8.0 \\
-3.9 \\
-6.4^{*}\end{array}$ \\
\hline Average & -1.9 & Average & -7.6 \\
\hline
\end{tabular}

* The antidiuretic activity of this extract after dialysis for an additional 3 hours was 6.0 sq. in. 


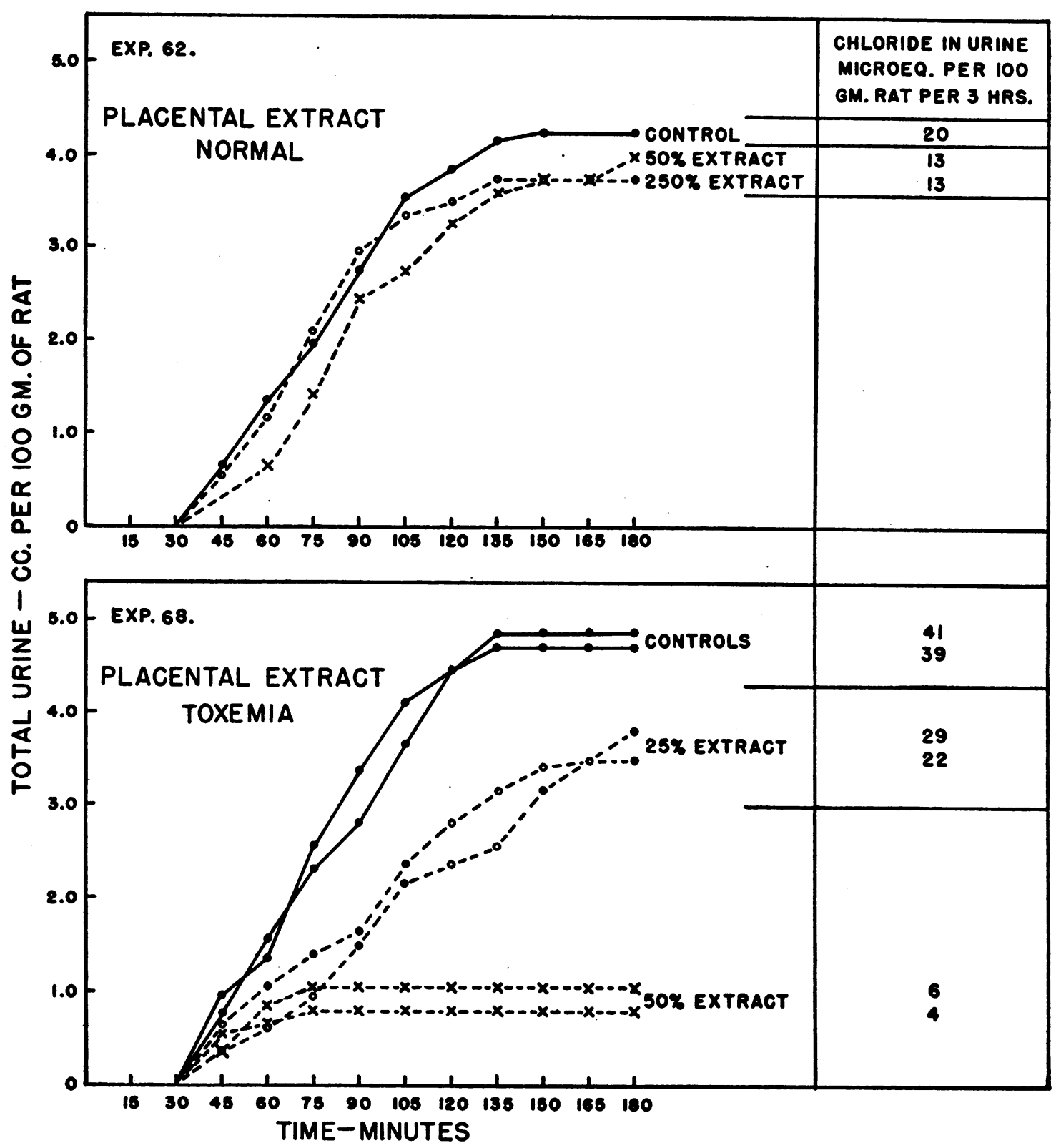

Fig. 6. Upper: Showing the Results of Assay of 50 Per Cent and 250 Per Cent Extracts of a Normal Placenta. Lower: Showing the Results of Assay of 25 Per Cent and 50 Per Cent Extracts of a Placenta from a Patient with Toxemia of Pregnancy

slightly antidiuretic. This patient, a 24-year-old colored primigravida, had a blood pressure of 220 $\mathrm{mm}$. $\mathrm{Hg}$ systolic and $140 \mathrm{~mm}$. $\mathrm{Hg}$ diastolic, bilateral choked discs, and retinal separation but no demonstrable edema. The other patients with toxemia all presented clinical edema with significant albuminuria and hypertension. Despite considerable variation, the average figures in Table $\mathrm{V}$ indicate that placentas from patients with toxemia contained considerably more antidiuretic substance than did placentas obtained after normal pregnancies.

The properties of the antidiuretic substance in placental extracts resembled those of the antidiuretic substance in the urine of these patients. (a) As shown in experiment 63 of Table V, 
dialysis for an additional 3 hours did not reduce the antidiuretic activity of the extract. (b) Ultracentrifugation of the extract of experiment 55 for 4 hours concentrated the antidiuretic substance in the lower fraction as shown in Figure 7. (c) Chloride excretion by the assay animals was tested in each instance and was never increased even during marked antidiuresis as shown in Figure 7 to the right.

While these results indicate that in the pregnant woman the placenta may contain antidiuretic material, still other sources must be considered to explain the excretion of antidiuretic substance by dehydrated male rats, male human subjects (8) and dehydrated non-pregnant women. Theobald and White (26), Walker (27) and Schaffer et al. (28) have reported that certain liver extracts are antidiuretic. Preliminary studies of our own have indicated also that crude 50 per cent saline extracts of rat livers are moderately antidiuretic but still have no effect on chloride excretion. A 50 per cent extract of abdominal muscle from the rat did not affect the excretion of either water or chloride.

With respect to extracts of kidney tissue, results are more complicated. Pickering and Prinzmetal (29) reported that rabbit kidney extract was definitely antidiuretic when injected into the dog but the same extract injected into the rabbit produced transient antidiuresis followed by copious diuresis and simultaneous increase in the excretion of both sodium and chloride. The diuresis and chloruresis were ascribed to renin, the antidiuresis was not studied.

Using a previously described method (30), 9 extracts were prepared from the normal kidneys of rabbits and rats. While antidiuretic activity was observed with certain concentrations and certain routes of injection, the results were complicated by the simultaneous or subsequent diuretic effect of renin. Of the tissues so far explored, nothing can be reported except that extracts of normal liver and kidney are probably moderately antidiuretic under certain conditions and that extracts of muscle are inactive. Further study is obviously necessary before conclusions can be drawn.

\section{DISCUSSION}

Evidence for (1 to 3,6) and against $(4,5,27)$ the thesis that the antidiuretic substance of urine arises in the pituitary glands has already been described. The results of comparing the anti-

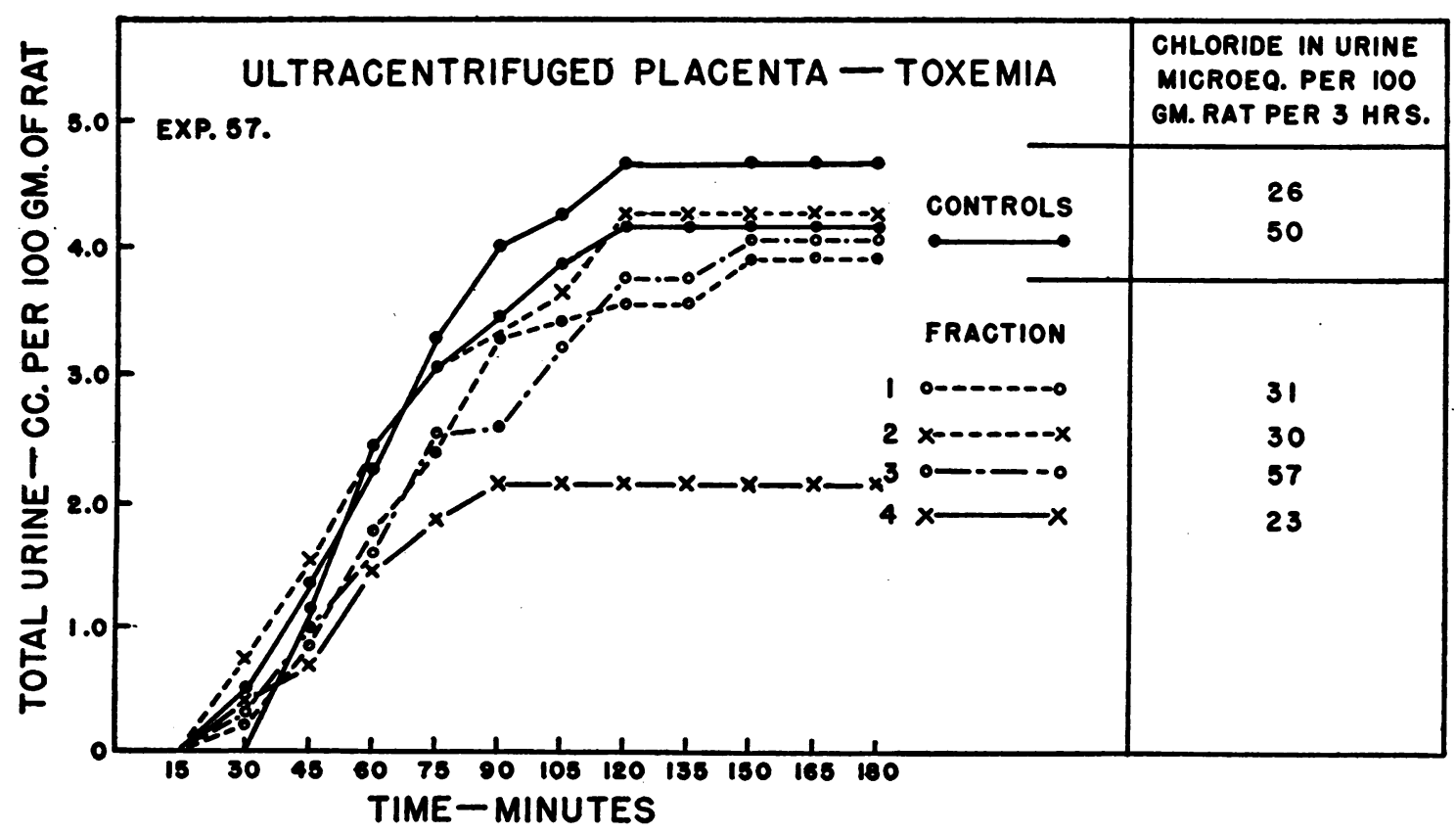

Fig. 7. Showing the Effect of Ultracentrifugation (4 hours at 60,000 R.P.M.) on the Antidiuretic and Chloruretic Activity of Placental Extract (Fractions numbered 1 to 4 from above downward) 
TABLE VI

Comparison of the antidiuretic substance in urine and in placental extracts with the antidiuretic substance of the pituitary gland prepared by 3 methods

\begin{tabular}{|c|c|c|c|}
\hline $\begin{array}{l}\text { Source of antidi- } \\
\text { uretic substance }\end{array}$ & $\begin{array}{c}\text { Excretion } \\
\text { of chlo- } \\
\text { rides in } \\
\text { urine }\end{array}$ & $\begin{array}{l}\text { Effect of ultra- } \\
\text { centrifugation }\end{array}$ & $\begin{array}{l}\text { Passage through } \\
\text { cellophane }\end{array}$ \\
\hline $\begin{array}{l}\text { Urine................ } \\
\text { Placental extract.... }\end{array}$ & $\begin{array}{l}\text { No effect } \\
\text { No effect }\end{array}$ & $\begin{array}{l}\text { Concentrated } \\
\text { Concentrated }\end{array}$ & $\begin{array}{l}\text { Not dialyzable } \\
\text { Not dialyzable }\end{array}$ \\
\hline $\begin{array}{l}\text { Commercial pituitrin } \\
\text { Saline extracts of pos- } \\
\text { terior lobes of pi- } \\
\text { tuitary glands.... } \\
\text { Press juice of pos- } \\
\text { terior lobes of pi- } \\
\text { tuitary gland..... }\end{array}$ & $\begin{array}{l}\text { Increased } \\
\text { Increased } \\
\text { Increased }\end{array}$ & \begin{tabular}{|l|} 
Not concentrated \\
Concentrated \\
Concentrated
\end{tabular} & $\begin{array}{c}\text { Dialyzable (rapid) } \\
\text { Dialyzable (slow) } \\
?\end{array}$ \\
\hline
\end{tabular}

diuretic substance in urine and placenta with the better known antidiuretic substance of the pituitary gland are summarized in Table VI. Though similar in reducing the excretion of water, these two substances differ most strikingly with relation to their effects on chloride excretion. The pituitary substance, prepared by three methods and administered in adequate dosage, always increased chloride excretion even when antidiuretic activity was barely detectable. The antidiuretic substance of urine always failed to affect chloride excretion, even when conspicuous antidiuresis was produced.

Ultracentrifugation and dialysis also demonstrated clear cut differences between commercial pituitrin and the antidiuretic substance of urine, but when more "natural" preparations of the posterior lobe of the pituitary gland were studied, these differences became relative rather than absolute. It is unfortunate that freshly prepared press juice was not available for dialysis but the results nevertheless indicate that the antidiuretic substance of pituitary gland in its "native" state is probably attached loosely to a protein. Its physical properties resemble to this extent those of the pressor and oxytocic substances of the pituitary gland as described by Rosenfeld (25).

It is conceivable that the urinary factor is concentrated by the ultracentrifuge and is undialyzable merely because a small molecule arising in the pituitary gland has, in the course of transportation and excretion, become attached to a large molecule. However, this does not explain the observation that the urinary substance does not affect chloride excretion. If the antidiuretic substance of urine actually originates in the pituitary gland it is necessary to postulate, in addition, a splitting of the chloruretic and the antidiuretic factors, with de- struction or neutralization of the former somewhere in the body. Separation of these factors has not yet been accomplished in vitro. This possibility in vivo is now being tested further in patients with diabetes insipidus by studying the antidiuretic and chloruretic activity of their urine before and after the administration of pitressin in moderate and large doses.

Another possibility is that the antidiuretic substance of urine originates in some organ or tissue other than the pituitary gland, and never did possess chloruretic activity. This explanation is supported by the presence, in extracts of placentas from patients with toxemia of pregnancy, of an antidiuretic substance which resembled, in the three respects tested, the antidiuretic factor found in the urine of these patients. Whether the placenta merely stored this antidiuretic substance, or actually produced it, cannot be stated at this time. The placenta is certainly not the only source of antidiuretic substance, because normal men and non-pregnant women excrete this factor in their urine if they are sufficiently dehydrated. Other possible sources are liver (27) and kidney (29). Extracts of liver, while antidiuretic, had no effect on chloride excretion, whereas kidney extract produced various effects consisting of mixtures of antidiuresis without effect on chloride excretion, and profound diuresis with marked increase in chloride excretion (29). Pickering and Prinzmetal believe diuresis and chloruresis to be the effect of renin. Injection of human kidney extracts into rabbits has demonstrated that antidiuresis is usually produced without affecting chloride excretion; in a few instances these extracts produced diuresis along with increase in chloride excretion (31) but these effects bore no relation to the existence of hypertension during life. No conclusion is warranted except that further studies of kidney extracts are needed.

The edema observed in cases of toxemia of pregnancy may be associated with a low plasma protein percentage, but in other instances cannot be adequately explained by the physical factors included in the Starling hypothesis. Teel and Reid (6) expressed the opinion that the antidiuretic substance found in the urine of patients with eclampsia could be related to water retention but not to the grade of hypertension. The importance of gross pathological changes in the 
placentas of toxemic patients has been suggested (32) but is not generally accepted (33). Weiss et al. (34) concluded that "the presence of a functioning placenta maintained the syndrome and removal of the placenta is responsible for improvement," but were unable to demonstrate any pressor factor in the placentas of patients with toxemia of pregnancy. Of considerable interest, therefore, are the findings $(a)$ that antidiuretic substance was found in urine of a patient with toxemia and hydatid mole, and $(b)$ that greater amounts of antidiuretic substance are found in the placentas of patients with toxemia of pregnancy than in those with normal pregnancies. It has also been found $(6,7)$ that after delivery the antidiuretic substance disappears rapidly from the urine of patients with toxemia of pregnancy as diuresis sets in.

To assay accurately the antidiuretic activity of urine may be more difficult than heretofore realized. Noble et al. (35) have reported that the urine contains augmentor substances which can produce erroneously high values for antidiuretic activity when pituitary extracts are injected subcutaneously. Schaffer et al. (28), using Walker's method (5), of collodion adsorption, reported that lower values of antidiuretic activity were obtained by the adsorption method than were found following dialysis of the same urine. It has often been assumed that the antidiuretic substance in urine arises in the pituitary gland and acts like pituitrin, but it has not been established that these properties apply also to the antidiuretic substance in urine. In agreement with Schaffer et al. (28), the present results indicate that in quantitative assays it would be best to compare the yield of the dialysis and adsorption methods with known amounts of urinary antidiuretic substance before far-reaching conclusions are drawn.

\section{CONCLUSIONS}

In agreement with previous observations, it was found that the urine from patients with toxemia of pregnancy contained large amounts of antidiuretic substance. Patients with hydatid mole ( 1 case) and hyperemesis gravidarum (3 cases) were also found to excrete significant amounts of antidiuretic substance.
Whereas commercial pituitrin was dialyzable through cellophane, was not concentrated by the ultracentrifuge, and increased chloride excretion in the urine, the antidiuretic substance in urine did not pass through cellophane, was concentrated by the ultracentrifuge, and did not affect chloride excretion in the urine.

The results so far indicate that an antidiuretic substance, differing in important respects from the hormone of the posterior pituitary, can appear in the urine of human beings.

Studies on fresh saline extracts and on press juice of the posterior lobe of the pituitary gland indicated that the antidiuretic and chloruretic factor of the pituitary dialyzed more slowly than did commercial pituitrin and could be concentrated by the ultracentrifuge. In this more "natural" state, however, the pituitary substance still retained quantitatively its effect upon chloride excretion, and still differed radically in this respect from the antidiuretic substance found in urine.

The placentas of patients with toxemia of pregnancy contained larger quantities of antidiuretic substance than did placentas from normal patients. The antidiuretic substance from placentas resembled in all three respects the antidiuretic substance found in urine of such patients. The liver and kidney are considered briefly as other possible sources of antidiuretic activity.

We wish to thank Dr. Alfred Chanutin for the use of the ultracentrifuge and Dr. Morris Rosenfeld for his generous supply of press juice. We are indebted to Mrs. Carolyn Carr and Mr. Herman Goslyn for technical assistance.

\section{BIBLIOGRAPHY}

1. Gilman, A., and Goodman, L., The secretory response of the posterior pituitary to the need for water conservation. J. Physiol., 1937, 90, 113.

2. Ingram, W. R., Ladd, L., and Benbow, J. T., The excretion of antidiuretic substance and its relation to the hypothalamico-hypophyseal system in cats. Am. J. Physiol., 1939, 127, 544.

3. Martin, S. J., Herrlich, H. C., and Fazekas, J. F., Relation between electrolyte imbalance and excretion of an antidiuretic substance in adrenalectomized cats. Am. J. Physiol., 1939, 127, 51.

4. Arnold, O., Uber blutdrucksteigernde und diuresehemmende Substanzen im Harn. Arch. f. exper. Path. u. Pharmakol., 1938, 190, 360.

5. Walker, A. M., Experiments upon the relation between the pituitary gland and water diuresis. Am. J. Physiol., 1939, 127, 519. 
6. Teel, H. M., and Reid, D. E., Observations upon the occurrence of an antidiuretic substance in the urine of patients with preeclampsia and eclampsia. Endocrinology, 1939, 24, 297.

7. Krieger, V. I., and Kilvington, T. B., Antidiuretic substance in urine in relation to normal and toxemic pregnancy. M. J. Australia, 1940, 1, 575.

8. Robinson, F. H., Jr., and Farr, L. E., The relation between clinical edema and the excretion of an antidiuretic substance in the urine. Ann. Int. Med., $1940,14,42$.

9. Anselmino, K. J., Hoffman, F., and Kennedy, W. P., The relation of hyperfunction of the posterior lobe of the hypophysis to eclampsia and the nephropathy of pregnancy. Edinburgh M. J., 1932, 39, 376.

10. Theobald, G. W., The alleged relation of hyperfunction of the posterior lobe of the hypophysis to eclampsia and the nephropathy of pregnancy. Clin. Sc., 1934, 1, 225.

11. de Wesselow, O. L. V. S., and Griffiths, W. J., On the question of pressor bodies in the blood of hypertensive subjects. Brit. J. Exper. Path., 1934, $15,45$.

12. Hurwitz, D., and Bullock, L. T., Failure to find pressor and antidiuretic substances in patients with toxemia of pregnancy. Am. J. M. Sc., 1935, 189, 613.

13. Byrom, F. B., and Wilson, C., The alleged pituitary origin of eclamptic and preeclamptic "toxaemias" of pregnancy. Quart. J. Med., 1934, 3, 361.

14. Levitt, G., The problem of an antidiuretic substance in the blood of patients with eclampsia and other hypertensive diseases, with observations on spinal fluid. J. Clin. Invest., 1936, 15, 135.

15. Melville, K. I., Antidiuretic pituitary substance in blood, with special reference to the toxemia of pregnancy. J. Exper. Med., 1937, 65, 415.

16. Marx, H., and Schneider, K., Untersuchungen zur Diurese; Uber den Nachweis antidiuretischer Substanzen im Blute. Arch. f. exper. Path. u. Pharmakol., 1934, 176, 24.

17. Burn, J. H., The estimation of the antidiuretic potency of pituitary (post. lobe) extracts. Quart. Jour. Pharm. and Pharmacol., 1931, 4, 517.

18. Silvette, $H$., The influence of post-pituitary extract on the excretion of water and chlorides by the renal tubules. Am. J. Physiol., 1940, 128, 747.

19. Ham, G. C. (To be published.)

20. Peters, J. P., and Van Slyke, D. D., Quantitative Clinical Chemistry. Methods. Williams \& Wilkins, Baltimore, 1932, p. 835.
21. Silvette, H., Effect of diminishing doses of postpituitary extract on urinary excretion of water and chlorides. Proc. Soc. Exper. Biol. and Med., 1940, 45, 599 .

22. Ham, G., and Rosenfeld, M., Ultracentrifugation of the antidiuretic, chloruretic, and pressor factors of posterior pituitary extracts. (To be published in Bull. Johns Hopkins Hosp.)

23. Beams, J. W., Linke, F., and Sommer, P. H., A vacuum type air-driven ultracentrifuge. Rev. Scient. Instruments, 1938, 9, 248.

24. Masket, A. V., A quantity type rotor for the ultracentrifuge. Rev. Scient. Instruments, 1941, 12, 277.

25. Rosenfeld, M., The native hormones of the posterior pituitary gland: The pressor and oxytocic principles. Bull. Johns Hopkins Hosp., 1940, 66, 398.

26. Theobald, G. W., and White, M., An antidiuretic substance extracted from the liver. J. Physiol., 1933, 78, 18 p.

27. Walker, A. M., An antidiuretic effect produced by certain preparations of heparin. Proc. Soc. Exper. Biol. and Med., 1938, 39, 105.

28. Schaffer, N. K., Cadden, J. F., and Stander, H. J., Measurement of antidiuretic activity as applied to eclamptic urine and properties of antidiuretic substance in rat urine, pituitary and beef liver. Endocrinology, 1941, 28, 701.

29. Pickering, G. W., and Prinzmetal, M., The effect of renin on urine formation. J. Physiol., 1940, 98, 314.

30. Landis, E. M., Jeffers, W. A., and Shiels, E. H., The pressor effects of homologous and heterologous injections of heated kidney extracts. Am. J. Physiol., 1940, 128, 672.

31. Landis, E. M., Unpublished observations.

32. Bartholomew, R. A., Pathology of the placenta with special reference to infarcts and their relation to toxemia of pregnancy. J. A. M. A., 1938, 111, 2276.

33. Harer, W. B., A study of one thousand placentas. Am. J. Obst. and Gynec., 1936, 32, 794.

34. Weiss, S., Dexter, L., Parker, F., Jr., and Tenney, B., Jr., Arterial hypertension in pregnancy and the hypertensive toxemia syndrome of pregnancy (preeclampsia and eclampsia). Tr. A. Am. Physicians, 1940, 55, 282.

35. Noble, R. L., Rinderkneckt, H., and Williams, P. C., The apparent augmentation of pituitary antidiuretic action by various retarding substances. J. Physiol., 1939, 96, 293. 